\title{
ORGANOCHLORINE PESTICIDES AND POLYCHLORINATED BIPHENYLS IN GAME ANIMALS FROM POLAND
}

\author{
ALICJA NIEWIADOWSKA, TOMASZ KILJANEK, STANISŁAW SEMENIUK, \\ AND JAN ŻMUDZKI
}

Department of Pharmacology and Toxicology,

National Veterinary Research Institute, 24-100 Pulawy, Poland

niewiado@piwet.pulawy.pl

Received: March 11, 2013

Accepted: May 15, 2013

\begin{abstract}
The occurrence and concentrations of organochlorine pesticides and polychlorinated biphenyls (PCBs) were determined in 141 adipose tissue samples of wild boars, roe deer, and red deer from different regions of the country, collected in 2010/2011. The determinations of $\mathrm{HCH}$ isomers $(\alpha-, \beta-$, and $\gamma-\mathrm{HCH}), \mathrm{HCB}$, DDTs (p,p'-DDT, o,p'-DDT, p,p'-DDE, and p,p'-DDD), and PCBs (six indicator PCB congeners $28,52,101,138,153$, and 180) were carried out using the capillary gas chromatography. The mean concentrations of DDTs expressed on the fat basis ranged from $0.241 \mathrm{mg} / \mathrm{kg}$ (wild boar) to $0.032 \mathrm{mg} / \mathrm{kg}$ (red deer), and for PCBs from $0.015 \mathrm{mg} / \mathrm{kg}$ (wild boar) to $0.010 \mathrm{mg} / \mathrm{kg}$ (roe deer). The mean contribution of p,p'-DDE to DDTs and PCB 153, PCB 138, and PCB 180 to PCBs exceeded $80 \%$ and $90 \%$ respectively, in all game animal samples studied. Higher contents of chlorinated hydrocarbons were detected in game animals originating from industrial regions.
\end{abstract}

Key words: game animals, organochlorine pesticides, PCBs, residues.

Organochlorine pesticides (OCPs) and polychlorinated biphenyls (PCBs) are representatives of a large group of chlorinated hydrocarbons, listed as persistent organic pollutants (POPs) in the Stockholm convention. Environmental pollution caused by these compounds has constituted a serious global problem for over half a century. They are widespread in air, water, soil, and live organisms including wildlife and humans. Many of these compounds, due to their environmental persistence, possess the ability to accumulate in the food chain, mainly in adipose tissues. It is widely known from the literature that exposure to certain POPs may result in serious environmental and health effects including adverse effects on the nervous, immune, endocrine, and reproductive systems, and may induce certain types of cancer $(1,14,15)$. The evaluation of food and environmental contaminations by chlorinated hydrocarbons began in the 1960s or early 1970s in many industrialised countries. Results of these studies led to introduction of restrictions and then prohibition of production and use of the organochlorine pesticides in agriculture and PCBs in industry. Studies on the OCP and PCB residues have become the basic element of each monitoring programme for food contamination.

Nowadays, none of pesticides containing the substances listed in the Stockholm convention are produced, used, imported, or exported in Poland. For over 30 years, the production of pesticides has been based on substances, which do not contain POPs. In 1972, DDT-containing pesticides were gradually withdrawn, and in 1975 the use of these chemicals was completely terminated. The use of pesticides containing HCB was permitted for the last time in 1978. Lindane was completely banned in Poland from 1988 to 1990. PCBs have never been produced in Poland on a technical scale. Only small quantities of Tarnol and Chlorofen were produced (below 1,000 ton).

The levels of POPs in wildlife animals reflect environmental contamination by these compounds $(2,5$, 7, 17). Game animals are good indicators of environmental contamination by chlorinated hydrocarbons. According to the Central Statistic Office, during the hunting season 2010/2011, 233,000 wild boars, 161,000 roe deer, and 54,000 red deer were shot (Concise Statistical Yearbook of Poland 2012).

The aim of the study was to monitor the occurrence and concentrations of organochlorine pesticides and indicator PCB congeners in adipose tissue of wild boars, roe deer, and red deer from different regions of Poland and to evaluate the possible toxicological hazard to the game meat consumer.

\section{Material and Methods}

Samples of adipose tissue from 84 wild boar (Sus scrofa), 32 red deer (Cervus elaphus), and 25 roe deer 
(Capreolus capreolus) were collected during the hunting season from August 2010 to January 2011. Sex, age, and weight were recorded for each animal. Wild boar (42 females and 42 males) aged between 1 and 5 years and weighed from 20 to $120 \mathrm{~kg}$. Red deer (17 females and 15 males) aged between 1 and 8 years and weighed from 24 to $156 \mathrm{~kg}$. Roe deer ( 22 females and three males) aged between 1 and 5 years and weighed from 11 to 45 $\mathrm{kg}$.

The studies were conducted in four industrial regions recognised as areas of significant environmental contamination, i.e. the Upper Silesian Industrial District (GOP, area around Miasteczko Śląskie and Tarnowskie Góry, mining industry, chemical industry), the LegnicaGłogów Copper District (LGOM, around Rudna, one of the biggest centres of cooper mining and industry in Poland), the Bełchatów Brown Coal Basin (vicinity of Bełchatów and Piotrków Trybunalski, coal mining industry), and the Turoszów Brown Coal Basin (area of Bogatynia, coal mining industry). As a reference area no industrialised region of Warmia and Mazury Lake District was selected.

The determination of organochlorine pesticides (HCB, $\alpha-\mathrm{HCH}, \beta-\mathrm{HCH}, \gamma-\mathrm{HCH}, \mathrm{p}, \mathrm{p}^{\prime}-\mathrm{DDE}, \mathrm{p}, \mathrm{p}^{\prime}-\mathrm{DDD}$, o,p'-DDT, p,p'-DDT) and six indicator PCB congeners (PCB IUPAC No. 28, 52, 101, 138, 153, 180) was carried out using a capillary gas chromatography with electron capture detection. Chlorinated hydrocarbons were extracted from the adipose tissue samples using mixture of hexane and acetone. The extracts were cleaned up on the basis of sulphuric acid treatment $\left(\mathrm{H}_{2} \mathrm{SO}_{4}+\mathrm{H}_{2} \mathrm{SO}_{4} \quad 25 \% \quad \mathrm{SO}_{3}\right)$, while separation of PCB congeners from OCPs was achieved with the use of alkaline hydrolysis $(10 \% \mathrm{KOH}$ in ethanol). The purified extracts were analysed by GLC-ECD.

Gas chromatographic analyses were performed on an Agilent Technologies model 6890 Plus equipped with 7683B series autosampler, split-splitless injector in pulsed splitless mode, and ${ }^{63} \mathrm{Ni}-\mu \mathrm{EC}$ detector. Chromatographic separation was achieved on HP-5MS capillary column $(60 \mathrm{~m} \times 0.25 \mathrm{~mm}$ ID $\times 0.25 \mu \mathrm{m}$ film thickness, J\&W Scientific, USA). The following oven temperature programme was used: initial temperature of $60^{\circ} \mathrm{C}$ for $2 \mathrm{~min}$, increase to $180^{\circ} \mathrm{C}$ at $40^{\circ} \mathrm{C} / \mathrm{min}$ and hold for $2 \mathrm{~min}$, increase to $245^{\circ} \mathrm{C}$ at $2^{\circ} \mathrm{C} / \mathrm{min}$ and hold $2 \mathrm{~min}$, increase to $265^{\circ} \mathrm{C}$ at $4^{\circ} \mathrm{C} / \mathrm{min}$ and hold for $15 \mathrm{~min}$, and then increase to $290^{\circ} \mathrm{C}$ at $8^{\circ} \mathrm{C} / \mathrm{min}$ and hold for $20 \mathrm{~min}$. For confirmatory purposes a second capillary column DB $1701(60 \mathrm{~m} \times 0.25 \mathrm{~mm}$ ID $\times 0.25 \mu \mathrm{m}$ film thickness, J\&W Scientific, USA) was used. The injector and detector were operated at $280^{\circ} \mathrm{C}$ and $325^{\circ} \mathrm{C}$, respectively. The GC was controlled by ChemStation software.

The study was carried out with the use of validated analytical methods in accredited laboratory. The validation was performed with the recommendations of the document SANCO/12495/2011 (Method validation and quality control procedures for pesticide residues analysis in food and feed). Validation parameters obtained for animal fat matrix demonstrate that the analytical method fulfil the method performance acceptability criteria. Recoveries from fortified samples were in the range $86 \%-102 \%$, coefficients of variation $(\mathrm{CV})$, indicating the precision of the methods, were $<12 \%$ for repeatability and $<15 \%$ for reproducibility, uncertainty $25 \%$, limit of determination was 0.001 $\mathrm{mg} / \mathrm{kg}$. The laboratory regularly and successfully participated in international proficiency testing organised by FAPAS (Food Analysis Performance Assessment Schemes, UK) and the European Union Reference Laboratory (CVUA Freiburg). In addition, the certified reference materials were analysed (CRM 430 Organochlorine pesticides in pork fat, CRM 445 and 446 - Chlorobiphenyls in pork fat).

\section{Results}

The presence of DDT and its metabolites has been observed in all 141 samples of adipose tissue of game animals. Residues of $\mathrm{p}, \mathrm{p}^{\prime}$-DDE occurred in all samples: p,p'-DDT in 53\%, and p,p'-DDD in 44\% of the samples. Among other examined pesticides, HCB and $\mathrm{HCH}$ isomers were detected. The low concentrations of HCB were found in $74 \%$ of the animals, in the range from traces to $0.025 \mathrm{mg} / \mathrm{kg}$. HCB was detected in $67 \%$ of samples from wild boar, in $75 \%$ of samples from red deer, and in all samples from the roe deer. Concentrations were low; mean and median content did not exceed $0.010 \mathrm{mg} / \mathrm{kg}$. Additionally, low contents of the isomers $\alpha$-, $\beta$-, and $\gamma-\mathrm{HCH}$ were detected in a few percentages of the samples with the mean concentration of about $0.002 \mathrm{mg} / \mathrm{kg}$ fat.

The occurrence of PCBs was detected in $98.6 \%$ samples. Only in two wild boars from the region of Warmia and Mazury PCB congeners were not identified. The most frequently detected $\mathrm{PCB}$ congeners were as follows: PCB 153 in $98.6 \%$ of the samples; PCB 138 in $97.9 \%$ of the samples, and PCB 180 in $94.3 \%$ of the samples. Other PCB congeners were detected only in some samples.

The results of determinations of DDTs and PCBs in fat of wild boars, roe deer, and red deer from different regions of Poland, are reported in Tables 1 and 2. The mean concentration of DDTs (sum of p, p'-DDE, p, p'DDD, o, p'-DDT, and p p'-DDT) in game animal fat was $0.157 \mathrm{mg} / \mathrm{kg}$, in that p,p'-DDE $0.129 \mathrm{mg} / \mathrm{kg}, \mathrm{p}, \mathrm{p}^{\prime}-\mathrm{DDT}$ $0.022 \mathrm{mg} / \mathrm{kg}, \mathrm{p}, \mathrm{p}^{\prime}-\mathrm{DDD} 0.007 \mathrm{mg} / \mathrm{kg}$, and o,p'-DDT $<0.001 \mathrm{mg} / \mathrm{kg}$. The results of individual samples ranged between $0.001 \mathrm{mg} / \mathrm{kg}$ and $2.490 \mathrm{mg} / \mathrm{kg}$. Values of median and $90^{\text {th }}$ percentile and $95^{\text {th }}$ percentile were $0.057 \mathrm{mg} / \mathrm{kg}, \quad 0.391 \mathrm{mg} / \mathrm{kg}$, and $0.638 \mathrm{mg} / \mathrm{kg}$, respectively. The mean concentration of PCBs in game fat was $0.014 \mathrm{mg} / \mathrm{kg}$; the results ranged from 0.001 $\mathrm{mg} / \mathrm{kg}$ to $0.164 \mathrm{mg} / \mathrm{kg}$.

The highest concentrations of pesticides were detected in tissues of wild boars. Mean concentration of DDTs in the fat was $0.241 \mathrm{mg} / \mathrm{kg}$ (median $0.140 \mathrm{mg} / \mathrm{kg}$ ). Concentrations in tissues of other game animals were several times lower and were on average $0.037 \mathrm{mg} / \mathrm{kg}$ (roe deer) and $0.032 \mathrm{mg} / \mathrm{kg}$ (red deer). Number of tested wild boars allowed to compare environmental 
contamination by chlorinated compounds between regions of animals' origin. In tissues of wild boars collected in four industrial regions, the concentrations of DDTs were several times higher (mean $0.309 \mathrm{mg} / \mathrm{kg}$ ) than in wild boar from the region of Warmia and Mazury (mean $0.071 \mathrm{mg} / \mathrm{kg}$ ). The highest levels of DDTs were found in wild boars from the LegnicaGłogów Copper District.

Mean concentration of PCBs in the tissues of wild boar was $0.015 \mathrm{mg} / \mathrm{kg}$ fat, in red deer $0.013 \mathrm{mg} / \mathrm{kg}$ fat, and in roe deer $0.010 \mathrm{mg} / \mathrm{kg}$ fat. In tissues of wild boars from industrial regions, few times higher concentrations of PCBs (mean $0.020 \mathrm{mg} / \mathrm{kg}$ ) were detected comparing to wild boar from the Mazury and Warmia region (mean $0.004 \mathrm{mg} / \mathrm{kg}$ ). The highest content of PCBs was found in the fat of wild boars from the Turoszów Brown Coal Basin (mean $0.032 \mathrm{mg} / \mathrm{kg}$ ).

The percentage of $\mathrm{p}, \mathrm{p}^{\prime}-\mathrm{DDE}$ in the total DDTs and the sum of PCB 153, 138, and 180 in the total PCBs was about $82 \%$ and $98 \%$, respectively (Fig. 1).

Table 1

Concentrations of DDTs and PCBs in adipose tissue of game animals ( $\mathrm{mg} / \mathrm{kg}$ fat)

\begin{tabular}{llcccccc}
\hline Species & $\begin{array}{c}\text { Number of } \\
\text { samples }\end{array}$ & Mean & Min-Max & Median & $\begin{array}{c}90^{\text {th }} \\
\text { percentile }\end{array}$ & $\begin{array}{c}95^{\text {th }} \\
\text { percentile }\end{array}$ \\
\hline \multirow{2}{*}{ DDTs } & Wild boar & 84 & 0.241 & $0.004-2.490$ & 0.140 & 0.572 & 0.795 \\
& Red deer & 32 & 0.032 & $0.002-0.083$ & 0.026 & 0.064 & 0.076 \\
& Roe deer & 25 & 0.037 & $0.001-0.141$ & 0.018 & 0.089 & 0.129 \\
\hline \multirow{2}{*}{ PCBs } & Wild boar & 84 & 0.015 & $0-0.164$ & 0.007 & 0.034 & 0.053 \\
& Red deer & 32 & 0.013 & $0.002-0.053$ & 0.007 & 0.025 & 0.036 \\
& Roe deer & 25 & 0.010 & $0.001-0.036$ & 0.005 & 0.025 & 0.027 \\
\hline
\end{tabular}

Table 2

Concentrations of DDTs and PCBs in adipose tissue of wild boars from different regions (mg/kg fat)

\begin{tabular}{|c|c|c|c|c|c|c|c|}
\hline & Regions & $\begin{array}{c}\text { Number of } \\
\text { samples }\end{array}$ & Mean & Min - Max & Median & $\begin{array}{c}90^{\text {th }} \\
\text { percentile }\end{array}$ & $\begin{array}{c}95^{\text {th }} \\
\text { percentile }\end{array}$ \\
\hline \multirow{5}{*}{ DDTs } & LGOM & 27 & 0.439 & $0.107-2.490$ & 0.240 & 0.829 & 1.397 \\
\hline & Bełchatów & 6 & 0.353 & $0.082-1.010$ & 0.264 & 0.714 & 0.862 \\
\hline & Bogatynia & 23 & 0.189 & $0.014-0.764$ & 0.142 & 0.310 & 0.574 \\
\hline & GOP & 4 & 0.049 & $0.014-0.140$ & 0.021 & 0.106 & 0.123 \\
\hline & Warmia and Mazury & 24 & 0.071 & $0.004-0.391$ & 0.037 & 0.193 & 0.206 \\
\hline \multirow{5}{*}{ PCBs } & LGOM & 27 & 0.011 & $0.001-0.046$ & 0.008 & 0.028 & 0.037 \\
\hline & Bełchatów & 6 & 0.009 & $0.003-0.028$ & 0.004 & 0.019 & 0.023 \\
\hline & Bogatynia & 23 & 0.032 & $0.002-0.164$ & 0.018 & 0.106 & 0.116 \\
\hline & GOP & 4 & 0.017 & $0.001-0.054$ & 0.007 & 0.041 & 0.048 \\
\hline & Warmia and Mazury & 24 & 0.004 & $0.001-0.017$ & 0.003 & 0.009 & 0.011 \\
\hline
\end{tabular}

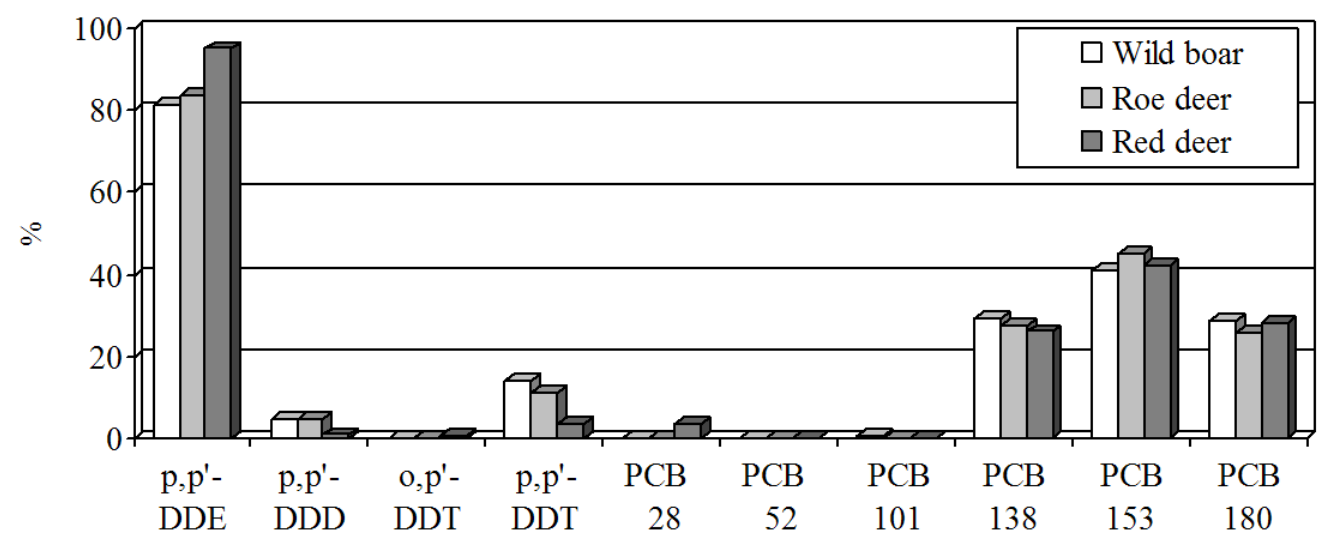

Fig. 1. Percentage contribution of DDT and its metabolites and PCB congeners in adipose tissue of game animals 


\section{Discussion}

In the previous monitoring studies conducted between 1995 and 2003 under the Programme of Polish Ministry of Agriculture and Rural Development, focusing on the quality of soils, plants, food, and agricultural products, 1,145 game animals were tested. Mean concentration of DDTs in the fat of wild boars was $0.501 \mathrm{mg} / \mathrm{kg}(1995-2003,511$ animals, median $0.272 \mathrm{mg} / \mathrm{kg})$, in roe deer $0.042 \mathrm{mg} / \mathrm{kg}(1995-2003,447$ animals, median $0.023 \mathrm{mg} / \mathrm{kg}$ ), and in red deer 0.029 $\mathrm{mg} / \mathrm{kg}$ (1996-2000, 187 animals, median $0.024 \mathrm{mg} / \mathrm{kg}$ ). Contents of DDTs exceeding MRL were identified in samples from 51 wild boars and one roe deer. Mean concentration of total PCBs (as Aroclor 1260) in the tissues of wild boars was $0.038 \mathrm{mg} / \mathrm{kg}$ fat, in roe deer $0.024 \mathrm{mg} / \mathrm{kg}$ fat, and in red deer $0.041 \mathrm{mg} / \mathrm{kg}$ fat. The concentration of organochlorine pesticides and PCBs did not differ significantly between 1995 and 2003. Results of monitoring from 1995 to 2003 were published in annual reports (8).

In Poland, the results of the long-term systematic studies have shown a significant decrease in the concentration of organochlorine pesticides and the trend of slow decline in the content of PCBs in farm animal tissues, milk, and eggs (11). In comparison with the results for game animals, obtained during these and other authors' investigations, the declines of the mean levels of chlorinated hydrocarbons have been also observed $(12,16,17)$. It can be assumed that contamination of roe deer and red deer by DDTs are now at the levels of $0.02-0.04 \mathrm{mg} / \mathrm{kg}$. It is obvious that tissues of wild boars contain higher levels of DDTs than those for other species of game animals. The levels of DDTs were probably related with the species feeding habits. Roe deer and red deer are herbivorous species. Wild boar is a typical omnivorous animal and gets feed mainly by digging the ground in forests. Soils are still contaminated with persistent chlorinated compounds (3, 4).

Comparison of the PCB results with the results of other authors appears to be complicated by the fact that the authors used a variety of analytical methods, different methods of sample preparation, and different ways to present the results (e.g., based on fat or tissue). In addition, the results of occurrence and contents of non dioxin-like PCBs in animals are presented in a variety of ways: as a sum of seven indicator PCB congeners IUPAC numbered 28, 52, 101, 118, 138, 153, and 180 (earlier EU recommendation), a sum of six congeners (PCB 28, 52, 101, 138, 153, and 180 - EFSA and EU recommendation), a sum of three congeners (PCB 138, 153, and 180) and even the only PCB 153, a sum of higher than seven selected congeners or as total PCBs (as e.g. Aroclors) $(5,6,7,9)$. The six PCB indicators were found to represent around $50 \%$ of the sum of the total PCBs, which were measured in the food samples. Results of the study show that contamination of game animals (wild boar, red deer, and roe deer) by PCBs (sum of six PCB indicators) in Poland is on the low level of $0.01-0.02 \mathrm{mg} / \mathrm{kg}$.
In order to protect consumers and to promote trade, maximum residue limits (MRLs) of pesticide residues in food of plant and animal origin are laid down in Regulation (EC) No 396/2005. MRLs in meat, expressed on fat bases of different species of farm animals for following pesticides have been established: DDTs $(1 \mathrm{mg} / \mathrm{kg}$ fat $), \mathrm{HCB}(0.2 \mathrm{mg} / \mathrm{kg}), \alpha-\mathrm{HCH}(0.2$ $\mathrm{mg} / \mathrm{kg}), \beta-\mathrm{HCH}(0.1 \mathrm{mg} / \mathrm{kg})$, and $\gamma-\mathrm{HCH}(0.02 \mathrm{mg} / \mathrm{kg})$. Among tested game animals, exceedance of MRLs was identified only in tissues of wild boars from industrial regions. Concentrations of DDTs exceeded the limit value in three wild boar samples and $\gamma-\mathrm{HCH}$, and $\beta$ $\mathrm{HCH}$ in one sample. Maximum levels (ML) for the sum of six non-dioxin like PCB indicators in food are laid down in the Commission Regulation (EU) No 1259/2011. PCB concentrations above $0.04 \mathrm{mg} / \mathrm{kg}$ (ML for cattle, pigs, and poultry) were found in fat of two red deer and six wild boars from industrial regions.

According to the available literature, the presence of residues of PCBs and some OCPs in tissues of game animals are still found in many countries $(2,5,6,7,10)$. Naccari et al. (9) studied the chlorinated hydrocarbon contamination of 154 samples from wild boars (heart, liver, lung, kidneys, muscle tissue, and spleen) from Calabria (south of Italy). The results have shown the presence of low residue concentration of DDTs only in eight livers, three kidneys, and one heart sample and lack of PCB (Aroclor 1232) residues. In another study from Italy, p,p'-DDE was detected in 95\% and PCBs (seven PCB indicator congeners) in $97 \%$ of the liver, and perirenal fat samples from roe deer resident in a protected area of the Emilia-Romagna region (10). Mean organochlorine concentrations from this study were comparable with the results obtained from the terrestrial herbivorous mammals from other parts of the word. Still, the problems with PCB contamination of food of animal origin in the areas of their former production occur. In Brescia (Italy) a PCB production plant, operated from 1930 to 1984 , polluted soil and forage of surrounding fields, and caused a significant contamination of meat and milk of the cattle fed local forage (13). The indicator PCB levels were about 100 times higher than the regional background. Another contamination case occurred in eastern Slovakia (7). In the Michalovce district, 25-years of the manufacture of PCB (Delors, from 1959 to 1984) resulted in increased environmental pollution of the surrounding area. Fish living in contaminated Michalovce waters contained about hundred times higher PCB levels than those captured in a control area. Similarly, game animals (deer, roe deer, wild boar, and duck) hunted in contaminated forests contained several times higher levels than those hunted in control area. The project's results have showed that the food and human population of the Michalovce district are much more contaminated with PCBs comparing to the rest of Slovakia.

In conclusion, the results of the study indicate that game animals from different parts of Poland have low contamination with the analysed chlorinated hydrocarbons. While assessing the results obtained for DDTs and PCBs in tissues of wild boars, red deer, and 
roe deer it should be noted that the mean concentrations of these compounds are similar and sometimes even lower to the results obtained by other authors investigating the samples of the same species. Due to environmental contamination, wild living animals can contain higher levels of PCBs, organochlorine pesticides, and other chemical contaminants than farm animals. The contents of DDTs and PCBs in game meat are not a hazard and should be considered safe for consumers. Further investigations on free-living animals as indicators of environmental pollution by chlorinated hydrocarbons should be continued.

Acknowledgments: The study was supported by the National Centre for Research and Development project No. 12-0127-10.

\section{References}

1. ATSDR (Agency for Toxic Substances and Disease Registry). Toxicological profile for DDT, DDE, and DDD. 2002.

2. Bachour G., Failing K., Georgii S., Elmadfa I., Brunn H.: Species and organ dependence of PCB contamination in fish, foxes, roe deer, and humans. Arch Environ Contam Toxicol 1998, 35, 666-673.

3. Covaci A., Manirakiza P., Schepens P.: Persistent organochlorine pollutants in soils from Belgium, Italy, Greece, and Romania. Bull Environ Contam Toxicol 2002, 68, 97-103.

4. Falandysz J., Brudnowska B., Kawano M., Wakimoto T.: Polychlorinated biphenyls and organochlorine pesticides in soils from the southern part of Poland. Arch Environ Contam Toxicol 2001, 40, 173-178.

5. Hoshi H., Minamoto N., Iwata H., Shiraki K., Tatsukawa R., Tanabe S., Fujita S., Hiraj K., Kinjo T.: Organochlorine pesticides and polychlorinated biphenyl congeners in wild terrestrial mammals and birds from Chubu region, Japan: Interspecies comparison of the residue levels and composition. Chemosphere 1998, 36, 3211-3221.

6. Herceg Romanic S., Marenjak T., Klincic D., Janicki Z., Srebocan E., Konjevic D.: Organochlorine compounds in red deer (Cervus elaphus L.) and fallow deer (Dama dama L.) from inland and coastal Croatia. Environ Monit Assess 2012, 184, 5173-5180.

7. Kocan A., Petrik J., Jursa S., Chovancowa J., Drobna B. Environmental contamination with polychlorinated biphenyls in area of former manufacture in Slovakia. Chemosphere 2001, 43, 595-600.

8. Michna W.: Reports on monitoring of the quality of soil, plants, food, and agricultural products. Ministry of Agriculture and Rural Development, Warsaw, Poland, 1995-2003.

9. Naccari F., Giofre F., Licata P., Martino D., Calo M., Parisi N.: Organochlorine pesticides and PCBs in wild boars from Calabria (Italy). Environ Monit Assess 2004, 96, 191-202.

10. Naso B., Zaccaroni A., Perrone D., Ferrante M., Severino L., Stracciari G., Lucisano A.: Organochlorine pesticides and polychlorinated biphenyls in European roe deer Capreolus capreolus resident in a protected area in Northern Italy. Sci Total Environ 2004, 328, 83-93.

11. Niewiadowska A., Żmudzki J.: Chlorinated hydrocarbons in animal tissues and products of animal origin from Poland. In: Global Contamination Trends of Persistent Organic Chemicals. Edited by Loganathan B. and Lam P.K.S, CRC Press, Taylor and Francis Group, Boca Raton, USA, 2011, pp. 337-353.

12. Szymczyk-Kobrzyńska K., Zalewski K.: DDT, HCH, and PCB residues in fat of red deer (Cervus elaphus) from the region of Warmia and Mazury, 2000-2001. Pol J Environ Stud 2003, 12, 613-617.

13. Turrio-Baldassarri L., Alivernini S., Carasi S., Casella M., Fuselli S., Iacovella N., Iamiceli A., Rocca C., Scarcella C., Battistelli C.: PCB, PCDD, and PCDF contamination of food of animal origin as the effect of soil pollution and the cause of human exposure in Brescia. Chemosphere 2009, 76, 278-285.

14. WHO (World Health Organization). DDT and its derivatives - environmental aspects. Environmental Health Criteria 83. WHO, Geneva, Switzerland, 1989.

15. WHO (World Health Organization). Polychlorinated biphenyls and terphenyls. Environmental Health Criteria 140. WHO, Geneva, Switzerland, 1993.

16. Zasadowski A.: Polychlorinated biphenyls (PCBs) in the adipose tissue of wild boars and roe-deer in the region of Warmia and Mazury. Pol J Environ Stud 1994, 3, 43-45.

17. Zasadowski A., Wyszyńska A., Wysocki A.: Evaluation of the contamination degree of roe-deer with cadmium and polychlorinated biphenyls in Warmia and Mazury district. Pol J Vet Sci 2003, 6, 93-97. 